(C) World Scientific Publishing Co.

and Center for Pacific Basin Business, Economics and Finance Research

DOI: $10.1142 /$ S0219091510002050

\title{
Intermediation Spread, Bank Supervision, and Financial Stability
}

\author{
Süheyla Özyıldırım \\ Faculty of Business Administration \\ Bilkent University \\ 06800 Bilkent Ankara, Turkey \\ suheyla@bilkent.edu.tr
}

This paper models the effect of bank competition and deposit insurance premiums on the spread between lending and deposit rates. In developing economies, low spreads do not always indicate bank efficiency; they may be the result of high risk taking. This paper shows that imposing upper and lower limits on banks' spreads and adjusting deposit insurance premiums when violation of these limits occurs leads to a more stable but relatively large intermediation costs. In developing economies, such an outcome would be considered more desirable because it insulates existing financial intermediaries and investors against macroeconomic disturbances.

Keywords: Intermediation spread; deposit market; insurance premium; banking; financial stability.

\section{Introduction}

Despite the importance of the spread between lending and deposit rates in the financial intermediation process, there are few theoretical and empirical studies on how that spread is determined. In the literature, much of the empirical work employs the dealership model originated by Ho and Saunders (1981) and its extensions by Allen (1988) and Angbazo (1997). In the work of Ho and Saunders, a bank is modeled as a dynamic dealer, setting interest rates on loans and deposits to balance the asymmetric arrivals of loan demands and deposit supplies. In that model, the main determinants of intermediation spread have market structure and risk premium components. Using a firm-theoretic approach, Wong (1997) finds similar evidence that optimal bank spread reacts positively to an increase in market power, credit risk, and interest rate risk. Saunders and Schumacher (2000) show that 
spreads vary widely within and across countries according to the degree of bank competition in each country.

Narrow spreads often indicate a relatively competitive banking sector, with lower intermediation costs. However, especially in developing and emerging markets, narrow spreads may not reflect the efficiency of financial intermediaries instead high risk taking against defaults and macroeconomic disturbances (Bethelemey and Varoudakis, 1996; Saunders and Schumacher, 2000; Koch, 2007). Laeven and Majnoni (2005) measure bank interest rate spreads for 106 countries and find that while interest rate spreads vary typically between $2 \%$ and $4 \%$ in developed financial systems, they often reach $10 \%$ and more in developing countries. Even though a relatively large spread between lending and deposit rates is purported to be better for solidifying a banking system, especially in a developing economy, to our knowledge, there has been no attempt to show explicitly the impact of regulatory practices on bank spread behaviors. The main purpose of this study, then, is to construct a model to analyze the determination of spread in a game-theoretical setting and show the effect of using a deposit insurance scheme as a supervisory tool to achieve larger but steadier intermediation spread profiles.

Modern banking regulation in most countries rests on three pillars: prudent regulation supervision with capital adequacy rules, deposit insurance with crisis management, and a regulatory framework that sets the rules for competition among banks (Allen et al., 2001). Boot et al. (2001) argue that the viability of the regulatory designs of minimum requirements for bank capital necessitates a well-developed financial system and adequate internal control systems. ${ }^{1}$ Moreover, capitalization ratio serves as an effective supervisory tool if changes in the market value of bank capital can be differentiated from the accounting value. The banking problems in developing countries in the 1990s indicated that capital requirements did not perform their expected supervisory tool. As highlighted by Rojas-Suarez (2001a), the year before the banking crises of 1991 in Sweden and Norway, and of 1994 in Japan, real equity growth became negative. In contrast, on the eve of crises in some developing countries (Argentina and Mexico in 1993, Ecuador in 1995, and Malaysia and Thailand in 1996), real equity growth reached very high positive levels. Gorton and Winton (1998) examine transition economies

\footnotetext{
${ }^{1}$ There are even exceptions in the developed markets. For example, Flannery and Rangan (2002) show that capital constraint was not binding at least for large banks in the 1990s in the United States. Moreover, Drummond et al. (2007) find that increasing competition in the loan and deposit markets in Italy did not materialize any efficiency gains in the banking sector.
} 
and find that raising capital requirements may make the banking system less risky at the cost of inefficiently small. Hence, adopting standards that are based on the risk characteristics of developed countries may not easily work for developing economies.

A risk-based deposit insurance premium is different than risk-based capital in that the premium explicitly prices risk rather than sets a standard. Although it does not offer a direct incentive-compatible mechanism, the risk-based premium system has some hidden potential if a bank has multiple objectives in their optimal spread choice. As emphasized by Avery and Belton (1987), it is very difficult to keep a bank's insurance premium confidential. Low-risk banks would have an incentive to advertise this fact and it might also be best for the bank in the regulatory sense.

The deregulation of financial markets and consolidation of banks around the globe in last two decade intensified the debates on the influences of concentration and competition in the banking industry. This trend in the banking industry has threatened the competitiveness of small or local banks. While large banks can afford to invest in technology and branch networks and offer services more convenient to the customer, small banks usually do not have the resources to fund such improvements. In general, small banks feel the competitive pressure of large banks both in the deposit and in the loan markets (see for example Hoshino and Turnbull (2002)). Keeley (1990) documents that the deregulation of the banking industry in the United States in the 1970s and 1980s led to an increase in competition and a reduction in banks profits. This in turn greatly increased the incentive for banks to undertake risk-taking behavior. Hellmann et al. (2000) show that with increased competition in the banking sector, especially in the race to acquire deposits, banks paying higher deposit rates gamble rather than practice prudent lending.

Overall, we suggest that in managing banking risks, the supervisory agency be allowed to set operating limits (upper and lower bounds) for bank spreads, which would be used to adjust the insurance premium for each bank. Thus, the examiner would endeavor to indirectly confine the movements of intermediation spreads. ${ }^{2}$ The lower limit of the spread would indicate the examiner's opinion of the level considered to be unsustainable during

\footnotetext{
${ }^{2}$ As discussed by Pyle (1974), during a period of rapidly rising short-term interest rates, Regulation $Q$ resulted from concern regarding the solvency of savings and loans banks. Although there may be similarities between our suggestion and Regulation $Q$, we do not suggest that Regulation $Q$ is better than competitive interest rates on deposit and loan contracts.
} 
macroeconomic or financial shocks. A smaller spread, i.e., a smaller buffer, would make banks more vulnerable against shocks. On the other hand, the upper boundary specifies the credit risk forbearance of each bank. In theory, competition should ensure that costs are minimized and prices of banking services are such that resources are allocated efficiently. However, if banks acquire market power, they can exploit it to charge higher interest on loans, pay lower interest on deposits and it may distort savings and investment decisions. Moreover, high interest rates that drive consumers and firms out of the credit market may increase the adverse selection problem. We argue that introducing such operation limits would bring more predictability and stability to intermediation spread, especially in a developing country.

In the literature, few studies suggest monitoring interest rates to control bank risk taking. Allen and Gale (2004) propose that bank regulators control bank spreads in order to limit possible inefficiencies resulting from excessive risk taking. Morgan and Ashcraft (2003) find strong evidence that lending rates were used to estimate the riskiness and future performance of business loans in US banks from 1984 to 2001. They argue that supervisors should consider using loan rates in their off-site surveillance, basing deposit insurance premiums on loan interest rates instead of (or in addition to) internal risk ratings. Using data for 3115 banks in 98 countries, Barth et al. (2008) find that increasing information asymmetry between bank owners and depositors or deposit insurers induces banks to shift more risk to depositors by allowing higher interest margins. They suggest that government regulation of banking sector should monitor these behaviors and establish a deposit insurance system to protect depositors and preserve stability of the banking system. Rojas-Suarez (2001b) documents evidence from several emerging economies that market indicators such as interest rate paid on deposits, spread between lending and deposit rates, and the rate of loan growth are better at predicting banking problems than traditional indicators such as capital-to-asset ratio, liquidity ratio, and/or equity prices. In a simulation analysis, Barnhill et al. (2004) show that different levels of bank credit risk, equity investment, bank-operating expenses, bank interest margin, and the future financial environments interact to determine bank risk levels. Thus, they suggest that maintaining loan prices adequately above credit costs (high intermediation spread) is crucial to maintain ultimately solvency of the banks.

In this paper, in a multi-period Bertrand competition for deposits among banks with different asset sizes, we show that if banking supervisory agencies audit the intermediation spread of competing banks and punish banks by adjusting deposit insurance premiums, banks may set intermediation spreads 
that insulate themselves against external and internal shocks. The remainder of the paper is organized as follows: Section 2 presents the deposit ratesetting game and its equilibriums under different deposit insurance schema. Section 3 summarizes the numerical experiments on the determination of optimal spreads and the merit of rate-based supervision. Section 4 concludes the paper.

\section{The Model}

Consider an economy with a monopolistic banking sector in which small $(s)$ and large $(l)$ banks compete to fund their loans with insured deposits. A typical bank chooses a stream of deposit rates to maximize its discounted expected profit over a fixed horizon:

$$
\max _{\left\{R_{D}^{i}\right\}_{t=1}^{T}} \sum_{t=1}^{T} \delta^{t}\left\{\left(1-\theta_{t}^{i}\right) R_{L t}^{i} L_{t}^{i}\left(R_{L t}^{i}\right)-\left(R_{D t}^{i}+\rho_{t}^{i}\right) D_{t}^{i}\left(R_{D t}^{i}, R_{D t}^{j}\right)\right\},
$$

where $i$ denotes small and large banks and $\delta$ is the common discount factor. $D_{t}^{i}$ and $L_{t}^{i}$ are deposit and loan contracts issued by bank $i$ at time $t$, respectively.

The deposit market is imperfect in the sense that the supply of deposit contracts for a specific bank, $D_{t}^{i}\left(R_{D t}^{i}, R_{D t}^{j}\right)$ is monotonically increasing in its own deposit interest rate, $R_{D}^{i}$, and decreasing in the rival bank's deposit rate, $R_{D}^{j}$ (see Boyd and de Nicoló, 2005). It is also assumed that the sensitivity of the supply of deposit contracts to interest rates by small and large banks is not uniform. More precisely, $\partial D_{t}^{s} / \partial R_{t}^{s}$ and $\partial D_{t}^{s} / \partial R_{t}^{l}$ are different than $\partial D_{t}^{l} / \partial R_{t}^{l}$ and $\partial D_{t}^{l} / \partial R_{t}^{s}$. This can be explained by several reasons. For example, large bank's competitiveness may improve if depositors believe that the government will treat these banks as "too big to fail". In other words, the perceived health of large banks presumably lowers the risk premiums they pay on their deposits (Bassett and Brady, 2001; Tirapat, 2002).

In addition to deposit interest rate, banks pay an insurance premium, $\rho$, to the deposit insurance agency, which makes the actual cost of deposit contracts as $\left(R_{D t}^{i}+\rho_{t}^{i}\right) D_{t}^{i}$. Banks use deposits to extend loans, risky and otherwise. It is assumed that loan contracts decline as lending rates increase, i.e., $\partial L_{t}^{i} / \partial R_{L t}^{i}<0$. Considering the fact that there is always a certain random percentage of non-performing loans, $\theta$, the actual value of loan payments to bank $i$ equals to $\left(1-\theta_{t}^{i}\right) R_{L t}^{i} L_{t}^{i}{ }^{3}$

\footnotetext{
${ }^{3}$ For simplicity, we assume that non-performing loans pay nothing to the bank as in Taggart and Greenbaum (1978) and Wong (1997).
} 
In the absence of an interbank market, the summation of bank capital, $K_{i}$, and the amount of deposits collected at each period, $D_{i t}$, determine the upper limit for funds allocated to loans (Barth et al., 2008). Intermediaries behave like asset transformers since they borrow in advance of the realization of uncertain loan demand (see Sealey, 1980; Deshmukh et al., 1983). Thus, by choosing $\left\{R_{D t}^{i} ; i=s, l\right\}_{t=1}^{T}$, each bank knows the total funds available for loan provisions. However, competition, especially in the deposit market, or more precisely, the deposit-stealing game, drives the deposit rate up, which may necessitate bank spread, $R_{L}-R_{D}$, to be more closely monitored in a volatile macroeconomic conditions.

In the literature, there are models in which banks compete first for deposits and then for loans (see for example, Yanelle, 1997). In this paper, competition in the loan market is linked to competition in the deposit market. Various explanations can be offered for assuming competition in the loan market in this way. First, it is generally accepted that loans are not as homogenous as deposits. ${ }^{4}$ Second, it can be argued that banks have actually been competing for a durable relationship in the loan market, ${ }^{5}$ but that does not necessitate low loan prices. Greenbaum et al. (1989), Sharpe (1990), Degryse and Van Cayseele (2000), and Zhu et al. (2009) provide theoretical and empirical evidence that the interest rate charged on a loan increases as the relationship lasts. Third, under an explicit and extensive deposit insurance scheme, because the adverse selection problem in the loan market becomes less important (Stein, 1998), there would be no risk in attempting to accumulate more insured deposits to be able to sell additional loans. Thus, bank $i$ announces the lending rate, $R_{L}^{i}$ such that the expected value of loan demand equals to the available source of funds, $D_{t}^{i}+K^{i}$. Since there is a probability that actual loan demand, $L_{t}^{i, d}$, is below or above the available funds, realized loan sales, $L_{t}^{i}$, will be either fully satisfied or rationed: $L_{t}^{i}=\operatorname{prob}\left(L_{t}^{i, d}<D_{t}^{i}+K^{i}\right) L_{t}^{i, d}+\operatorname{prob}\left(L_{t}^{i, d} \geq D_{t}^{i}+K^{i}\right)\left(D_{t}^{i}+K^{i}\right) \cdot{ }^{6}$

\footnotetext{
${ }^{4}$ It can be argued that Certificates of Deposit (CDs) are not as homogenous as demand deposits because CDs are uninsured source of funds for the banks. Yet, issuing CDs is not easy for small banks due to information costs.

${ }^{5}$ Even though there is still controversy over the benefits of relationship lending, optimal contracts under relationship lending allow for intertemporal arrangements, lowering aggregate financing costs and reducing credit rationing (see Greenbaum et al., 1989; Sharpe, 1990; Boot and Thakor, 1994; Petersen and Rajan, 1995; Elsas and Krahnen, 1998).

${ }^{6}$ For simplicity, the cost of idle resources $\left(L_{t}^{i, d}<D_{t}^{i}+K^{i}\right)$ and the benefit from excess loan demand $\left(L_{t}^{i, d}>D_{t}^{i}+K^{i}\right)$ are ignored in the profit function.
} 
The ratio of non-performing loans for a bank, $\theta_{t}^{i}$, is described as a function of loan rate, $R_{L}$,

$$
\theta_{t}^{i}=h\left(\bar{\theta}_{t}^{i}, R_{L t}^{i}\right), \quad 0 \leq \theta_{t}^{i} \leq 1,
$$

where $h$ is any convex function in $R_{L}$ and $\bar{\theta}_{t}^{i}$ denotes the random default rate, which is independent of the level of lending. In Equation (2), a higher interest rate suggests a higher default premium for the borrower.

In this economy, the deposit insurance agency determines the insurance premiums and manages the deposit insurance fund. The compulsory deposit insurance premium, $\rho_{t}^{i}$, is determined as follows:

$$
\rho_{t}^{i}= \begin{cases}\rho+\psi_{1}\left(\theta_{t-1}^{i}\right)+\psi_{2}\left(\mu_{t-1}^{i}\right), & \text { if } \mu_{t-1}^{i} \notin[\underline{\mu}, \bar{\mu}] \\ \rho+\psi_{1}\left(\theta_{t-1}^{i}\right), & \text { otherwise. }\end{cases}
$$

In addition to the flat rate, $\rho$, the insurance premium for bank $i$ is adjusted to the risk exposures of that bank at the end of each period. First, the actual premium increases with an increase in non-performing loans $\left(\partial \psi_{1} / \partial \theta_{t-1}^{i}>\right.$ $0)$. Second, the bank pays a higher premium to the insurance fund when the chosen lending and deposit rates cause the spread, $\mu^{i}\left(=R_{L}^{i}-R_{D}^{i}\right)^{7}$ to signal increased risks for bank $i$. To be more specific, when the spread is above a certain upper limit, $\bar{\mu}$, it will be considered an indication of high risk taking by the bank. Similarly, when the spread is below a certain level, $\mu$, the bank is considered to be exposed to both interest rate risk and credit risk. Thus, when the previous period's spread violates the pre-specified operating limits or surveillance band, i.e., $\mu_{t-1}^{i} \notin[\underline{\mu}, \bar{\mu}]$, the insurance premium increases by $\psi_{2}$. In this paper, the supervisory agency is modeled to achieve macroeconomic stability and prudent banking practices by monitoring the intermediation cost of each bank over time (see also Freixas and Rochet, 1997). Using data from 71 countries, Pasiouras et al. (2006) show that banks in countries where deposit insurer has more power to intervene or to take an action against risk taking have higher ratings. In a static framework, Matutes and Vives (2000) and Cordella and Yeyati (2002) explore the impact of competition for deposits on risk-taking behavior under different deposit insurance schema. In particular, Cordella and Yeyati (2002) emphasize the role of the

\footnotetext{
${ }^{7}$ Since supervisors are assumed to monitor the previous period's prices for loan and deposit contracts, these rates are effectively not ex ante (or contract) interest rates. Even though there might be practical difficulties with monitoring and regulating spreads, Barajas et al. (1999), for example, mention the Colombian Banking Superintendency, which collects information on lending and deposit rates for all banks on the last week of each month as a way of supervision.
} 
deposit insurance agency on managing the qualities of banks' portfolios. They show that by charging risk-based insurance premiums, banks would be disciplined in competitive banking environments. This paper will utilize a similar argument but a different scheme to adjust deposit insurance premiums.

\section{Equilibrium Under Different Insurance Schema}

The Bertrand equilibrium of the deposit game described in Section 2 is determined when each bank chooses its profit-maximizing deposit rate based on expectations of the rival's rate under given deposit insurance system. In the flat rate, $\rho$, deposit insurance scheme, an optimal stream of deposit rates is obtained as follows.

Flat-Rate Premium:

$$
\begin{aligned}
-R_{L t}^{i} L_{t}^{i} \frac{\partial \theta_{t}^{i}}{\partial R_{D t}^{i}}+\left(1-\theta_{t}^{i}\right)\left[\frac{\partial R_{L t}^{i}}{\partial R_{D t}^{i}} L_{t}^{i}+R_{L t}^{i} \frac{\partial L_{t}^{i}}{\partial R_{D t}^{i}}\right] & -D_{t}^{i}\left(R_{D t}^{i}, R_{D t}^{j}\right) \\
& -\left(R_{D t}^{i}+\rho\right) \frac{\partial D_{t}^{i}}{\partial R_{D t}^{i}}=0,
\end{aligned}
$$

where $i=s, l$ and $t=1, \ldots, T$. $^{8}$

Equation (4) is an implicit function that defines the profit-maximizing levels of deposit rates, $\left\{R_{D t}^{i}\right\}_{t=1}^{T}$ for any given deposit rate of rival bank, $\left\{R_{D t}^{j}\right\}_{t=1}^{T}$. Solving Equation (4) for $R_{D t}^{i}$ gives bank $i$ 's reaction function, $R_{D}^{i}\left(R_{D}^{j}\right)$. In an analogous manner, the reaction function for bank $j$ defines $R_{D}^{j}\left(R_{D}^{i}\right)$. The intersection of two reaction functions yields the equilibrium levels of deposit rates for small and large banks, ${ }^{9}\left\{R_{D t}^{i *} ; i=s, l\right\}_{t=1}^{T}$, under a flat rate insurance scheme.

Spread-and/or Risk-Adjusted Premium:

In the case where the deposit insurance agent adjusts the deposit premium of each bank according to the bank's non-performing loan rate and intermediation spread in the previous period, $\rho_{t}^{i}=\rho+\psi_{1}\left(\theta_{t-1}^{i}\right)+\psi_{2}\left(\mu_{t-1}^{i}\right)$,

\footnotetext{
${ }^{8}$ The choice of deposit rate, $R_{D t}^{i}$, will affect loan sales and the proportion of nonperforming loans as $\partial \theta_{t}^{i} / \partial R_{D t}^{i}=\left(\partial \theta_{t}^{i} / \partial R_{L t}^{i} \partial R_{L t}^{i} / \partial L_{t}^{i}\right)\left(\partial L_{t}^{i} / \partial D_{t}^{i} \partial D_{t}^{i} / \partial R_{D t}^{i}\right)$, for bank $i=s, l$. Moreover, the lending rate and the available fund for credits depend on the choice of deposit rates at each period: $\partial R_{L t}^{i} / \partial R_{D t}^{i}=\left(\partial R_{L t}^{i} / \partial L_{t}^{i}\right)\left(\partial L_{t}^{i} / \partial D_{t}^{i} \partial D_{t}^{i} / \partial R_{D t}^{i}\right)$ and $L_{t}^{i} / \partial R_{D t}^{i}=\partial L_{t}^{i} / \partial D_{t}^{i} \partial D_{t}^{i} / \partial R_{D t}^{i}$.

${ }^{9}$ See, for example, De Zeeuw and van der Ploeg (1991) for derivations of the Nash equilibrium in a dynamic games setting.
} 
the necessary condition for obtaining an optimal deposit rate for bank $i$, becomes:

$$
\begin{aligned}
&-R_{L t}^{i} L_{t}^{i} \frac{\partial \theta_{t}^{i}}{\partial R_{D t}^{i}}+(1-\left.\theta_{t}^{i}\right)\left[\frac{\partial R_{L t}^{i}}{\partial R_{D t}^{i}} L_{t}^{i}+R_{L t}^{i} \frac{\partial L_{t}^{i}}{\partial R_{D t}^{i}}\right]-D_{t}^{i}\left(R_{D t}^{i}, R_{D t}^{j}\right) \\
&-\left(R_{D t}^{i}+\rho_{t}^{i}\right) \frac{\partial D_{t}^{i}}{\partial R_{D t}^{i}}-\delta\left[\frac{\partial \rho_{t+1}^{i}}{\partial R_{D t}^{i}} D_{t}^{i}\left(R_{D t}^{i}, R_{D t}^{j}\right)\right]=0,
\end{aligned}
$$

where

$\frac{\partial \rho_{t+1}^{i}}{\partial R_{D t}^{i}}=\frac{\partial \psi_{1}}{\partial R_{L t}^{i}} \frac{\partial R_{L t}^{i}}{\partial R_{D t}^{i}}-\frac{\partial \psi_{1}}{\partial R_{D t}^{i}}+\frac{\partial \psi_{2}}{\partial \theta_{t}^{i}} \frac{\partial \theta_{t}^{i}}{\partial R_{L t}^{i}} \frac{\partial R_{L t}^{i}}{\partial R_{D t}^{i}}, \quad$ for $i=s, l, t=1, \ldots, T$.

Similar to the derivation of the equilibrium in the flat rate model, the reaction functions using Equation (5) and a simultaneous solution of these equations yield the optimal deposit rates for small and large banks under spread-based and/or risk-based premium schema.

\subsection{Derivation of intermediation spread}

To determine the optimal spread profiles, $\left\{\mu_{t}^{i *} ; i=s, l\right\}_{t=1}^{T}$, first, the noncooperative deposit game between small and large banks is solved. From the equilibrium deposit rates, $\left\{R_{D t}^{s *}, ; R_{D t}^{l *}\right\}_{t=1}^{T}$, the amount of deposit supplied, $D_{t}^{i *}\left(R_{D t}^{i *}, ; R_{D t}^{j *}\right)$, and the available loanable funds, $D_{t}^{i *}+K^{i}$, for bank $i=s, l$ can be calculated. As described in the model, loans are sold at a rate, $R_{L t}^{i}$, where the loan demand, $L_{t}^{i, d}$, and supply, $D_{t}^{i *}+K^{i}$, are in equilibrium: $L_{t}^{i, d}=f\left(R_{L t}^{i}\right)=D_{t}^{i *}+K^{i}$, or $R_{L t}^{i}=f^{-1}\left(D_{t}^{i *}+K^{i}\right)$. Thus, the difference between the announced loan rate and the optimal deposit rate would be the optimal spread, $\mu_{t}^{i *}\left(=R_{L t}^{i}-R_{D t}^{i *}\right)$, for bank $i$ at time $t$.

In the solution procedure described above, it is assumed that banks choose their respective plans at an initial date. This class of equilibrium can be argued to be appropriate for games in the deposit market. The empirical evidence shows that prices are mostly rigid in the deposit market. Numerous explanations are offered for the existence of price stickiness: For example, Hannan and Berger (1991) look to menu costs. Their result shows that if there is a cost to changing a bank's interest rate (menu cost), then changes are made only when the rates are out of line enough to make it worth the menu cost. They also find that deposit rates are significantly more rigid when deposit bank interest rates are increasing.

A number of papers modeling strategic interaction in the banking industry consider the Cournot (see Hannan and Berger, 1991; Montgomery, 1991) or Bertrand competition (see Yannelle, 1997; Dell'Ariccia et al., 1999). For our purpose, since spread is the main variable to be monitored by supervisory 
agents, the Bertrand model is more appropriate. As far as the financial industry is concerned, previous empirical results generally confirm that it is very hard to maintain a monopolistic position in the financial market (Tufano, 1989; Britran and Lojo, 1993). Once a company promotes a new product (or price) other competitors could not only copy it immediately but also invent a better product (or offer a better price), because they have time to learn the strengths and weaknesses of the product. From the very few studies that examine other game structures such as the Stackelberg competition, Zhou et al. (2009) found an unexpected result: state-owned banks in China are acting as followers to improve social welfare.

\section{Numerical Analysis of Equilibrium}

\subsection{Calibration of the model}

To derive the time paths of spreads for small and large banks, we calibrate the model and numerically examine the effect of the proposed supervision of banks. To study the role of the deposit insurance premium on achieving stable bank spread behavior, first, it is assumed that deposit supply function is simply linear: $D_{t}^{i}=\alpha_{i}+\beta_{i} R_{D t}^{i}-\gamma_{i} R_{D t}^{j}$, where $\alpha_{l}=20, \alpha_{s}=10, \beta_{l}=4000$, $\beta_{s}=3000, \gamma_{l}=300$, and $\gamma_{s}=600 .^{10}$ It is assumed that large banks are less sensitive to changes in deposit rates compared to small banks because they have more capacity for loan sales. Moreover, they are assumed to be less cross-price elastic.

Loan demand is characterized as $L_{t}^{i}=\left(R_{L t}^{i}\right)^{a}$, where $a=-0.30 .{ }^{11}$ Banks are assumed to be confronted with stochastic arrivals of borrowers that follow a Poisson distribution (see Ho and Saunders, 1981)

$$
\operatorname{prob}\left(L_{t}^{d}\right)=\frac{e^{-\lambda_{t}} \lambda_{t}^{L_{t}^{d}}}{L_{t}^{d} !} \text { for } L_{t}^{d}=0,1, \ldots,
$$

where $\lambda_{t}=D_{t}+K$ and the expected loan demand, $E\left[L_{t}^{d}\right]$, equals $\lambda_{t}$. In the numerical experiments, the integer values of loan demands with a mean of $D_{t}^{i}+K^{i}$ are generated using the algorithm described in Knuth (1981).

The flat rate deposit insurance premium is set at 0.05 (5\% of the deposits supplied). On top of this rate, the actual premium increases with the existence of non-performing loans, such that $\psi_{1}=0.5 \theta_{t-1}^{i}$. The upper

\footnotetext{
$\overline{{ }^{10} \text { See Barro (1976) }}$ and Fry (1988) for the selection of certain parameters on deposit and loan functions and the constant default rate.

${ }^{11}$ Note that the interest rate elasticity of loan demand is assumed to be constant, whereas the interest rate elasticity of deposit supply changes over $R_{D}^{i}$.
} 
and lower operating limits for bank spreads are chosen as $\underline{\mu}=0.10$ and $\bar{\mu}=0.25$ especially to see how the model will perform in less-developed and more volatile macroeconomic environments. If the last period's spread of any bank is within the specified limits, the actual premium for deposit insurance would be $\rho_{t}^{i}=0.05+0.5 \theta_{t-1}^{i}$. Otherwise, i.e., $\mu_{t}^{i} \notin[\bar{\mu}, \mu]$, banks would have to pay an additional flat rate of $3 \%\left(\psi_{2}=0.03\right)$ to the deposit insurance fund. The default rate is described as $\theta_{t}^{i}=\bar{\theta}_{t}^{i}+\Theta\left[0.2\left(R_{L t}^{i}-R_{\text {max }}^{i}\right)\right]$, where $h$ is a linear for simplicity. $\bar{\theta}_{t}^{i}$ is generated as a uniform random deviate between $3 \%$ and $5 \% . \Theta$ is an indicator function that equals one if the loan rate is above a certain threshold rate, $R_{\max }^{i}$, and equals zero otherwise. Stiglitz and Weiss (1981) call $R_{\max }$ the bank-optimal lending rate because it is the interest rate at which the expected return to the bank is maximized. $R_{\max }^{i}$ is 0.15 for both types of banks. Other parameters are $\delta=0.98$, and the surveillance horizon, $T$ is 30 periods (for example, 30 days or 30 weeks).

\subsection{Numerical results}

Figures 1-5 illustrate the optimal time profiles of intermediation spread under flat rate versus adjusted-rate premium schema. In Figure 1, it is
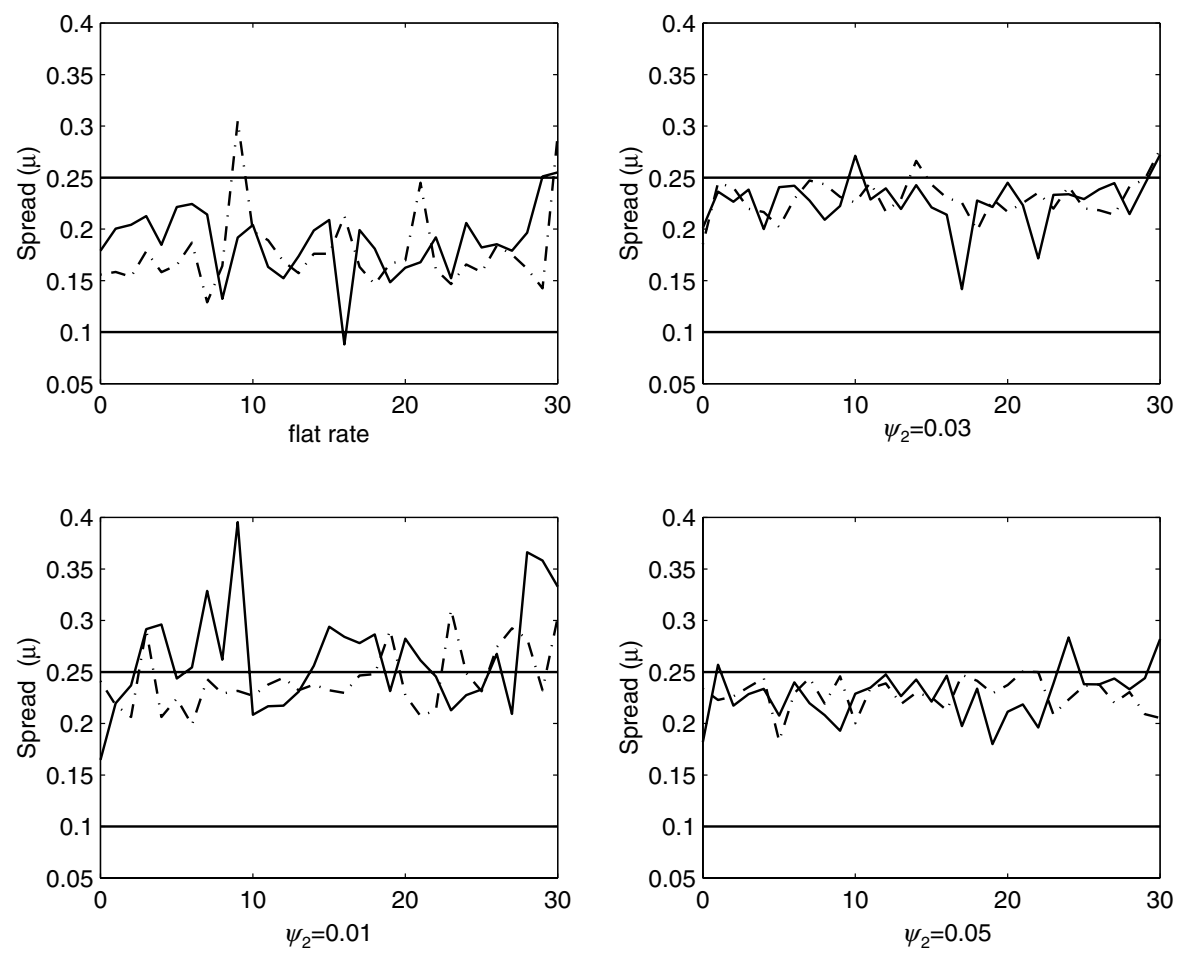

Fig. 1. Spread profiles for flat rate $(\rho=0.05)$ versus adjusted-rate premiums where dotted lines indicate large banks. 
Table 1. Mean values for spread, deposit, and loan rates.

\begin{tabular}{|c|c|c|c|c|c|c|}
\hline & \multirow[b]{3}{*}{$\rho$} & \multicolumn{5}{|c|}{ Adjusted-Rate Premium $\left(\rho_{t}^{i}\right)$} \\
\hline & & \multicolumn{3}{|c|}{$\psi_{2}$} & \multicolumn{2}{|c|}{$\psi_{2}=0.03, \underline{\mu}=0.1$} \\
\hline & & 0.01 & 0.03 & 0.05 & $\bar{\mu}=0.2$ & $\bar{\mu}=0.3$ \\
\hline$\mu^{l}$ & $\begin{array}{c}0.1778 \\
(0.0389)\end{array}$ & $\begin{array}{c}0.2432 \\
(0.0301)\end{array}$ & $\begin{array}{c}0.2300 \\
(0.0187)\end{array}$ & $\begin{array}{c}0.2281 \\
(0.0158)\end{array}$ & $\begin{array}{c}0.2545 \\
(0.0342)\end{array}$ & $\begin{array}{c}0.2414 \\
(0.0284)\end{array}$ \\
\hline$\mu^{s}$ & $\begin{array}{c}0.1875 \\
(0.0333)\end{array}$ & $\begin{array}{c}0.2643 \\
(0.0519)\end{array}$ & $\begin{array}{c}0.2265 \\
(0.0250)\end{array}$ & $\begin{array}{c}0.2282 \\
(0.0244)\end{array}$ & $\begin{array}{c}0.2965 \\
(0.0473)\end{array}$ & $\begin{array}{c}0.2488 \\
(0.0250)\end{array}$ \\
\hline$R_{D}^{l}$ & $\begin{array}{c}0.0381 \\
(0.0120)\end{array}$ & $\begin{array}{c}0.0155 \\
(0.0064)\end{array}$ & $\begin{array}{c}0.0186 \\
(0.0050)\end{array}$ & $\begin{array}{c}0.0190 \\
(0.0044)\end{array}$ & $\begin{array}{c}0.0129 \\
(0.0082)\end{array}$ & $\begin{array}{c}0.01600 \\
(0.0069)\end{array}$ \\
\hline$R_{D}^{s}$ & $\begin{array}{c}0.0459 \\
(0.0140)\end{array}$ & $\begin{array}{l}0.02116 \\
(0.0106)\end{array}$ & $\begin{array}{l}0.02943 \\
(0.0087)\end{array}$ & $\begin{array}{c}0.02896 \\
(0.0070)\end{array}$ & $\begin{array}{c}0.01433 \\
(0.0091)\end{array}$ & $\begin{array}{l}0.02303 \\
(0.0060)\end{array}$ \\
\hline$R_{L}^{l}$ & $\begin{array}{c}0.2159 \\
(0.0272)\end{array}$ & $\begin{array}{c}0.2587 \\
(0.0238)\end{array}$ & $\begin{array}{c}0.2486 \\
(0.0137)\end{array}$ & $\begin{array}{c}0.2471 \\
(0.0114)\end{array}$ & $\begin{array}{c}0.2674 \\
(0.0264)\end{array}$ & $\begin{array}{c}0.2573 \\
(0.0217)\end{array}$ \\
\hline$R_{L}^{s}$ & $\begin{array}{c}0.2334 \\
(0.0197)\end{array}$ & $\begin{array}{c}0.2855 \\
(0.0419)\end{array}$ & $\begin{array}{c}0.2560 \\
(0.0165)\end{array}$ & $\begin{array}{c}0.2572 \\
(0.0175)\end{array}$ & $\begin{array}{c}0.3108 \\
(0.0388)\end{array}$ & $\begin{array}{c}0.2718 \\
(0.0192)\end{array}$ \\
\hline
\end{tabular}

Note: Standard deviations in parentheses.

observed that spread volatility for both types of banks decreases for higher values of $\psi_{2}$. When the optimal spreads deviate from the operating limits a higher compensating premium on the flat rate yields less intertemporal volatility of intermediation costs. However, this adjustment on the deposit insurance premium scheme increases the overall levels of optimal spreads. In Table 1, the mean values and the standard deviations of intermediation prices, $\left\{R_{D}^{i}, R_{L}^{i} ; i=s, l\right\}$ and the spreads for both types of banks are reported for the insurance schemes of flat rate versus adjusted rate.

As seen from Figure 2, intermediation prices change significantly when banks compete for deposits under the system where spreads are closely monitored by the supervisory agent. In the insurance system where the riskadjusted premium might be $3 \%$ more than the flat rate $\left(=\psi_{2}\right)$, it is observed that both types of banks decrease their deposit rates as well as increase their loan rates. Thus, the optimal spread profiles of small and large banks move to higher levels, even closer to $\bar{\mu}$ (see Figure 1). Therefore, the relatively tight regulation suggested in this paper brings a more stable movement of optimal spreads, albeit lower intermediation benefits, to the banks' potential users. Even though the competitive outcomes are expected to yield higher deposit rates and lower loan rates, the opposite behavior is observed in both the deposit and the loan markets. Despite the deposit-stealing game among banks, the outcome of the non-cooperative deposit game described herein 

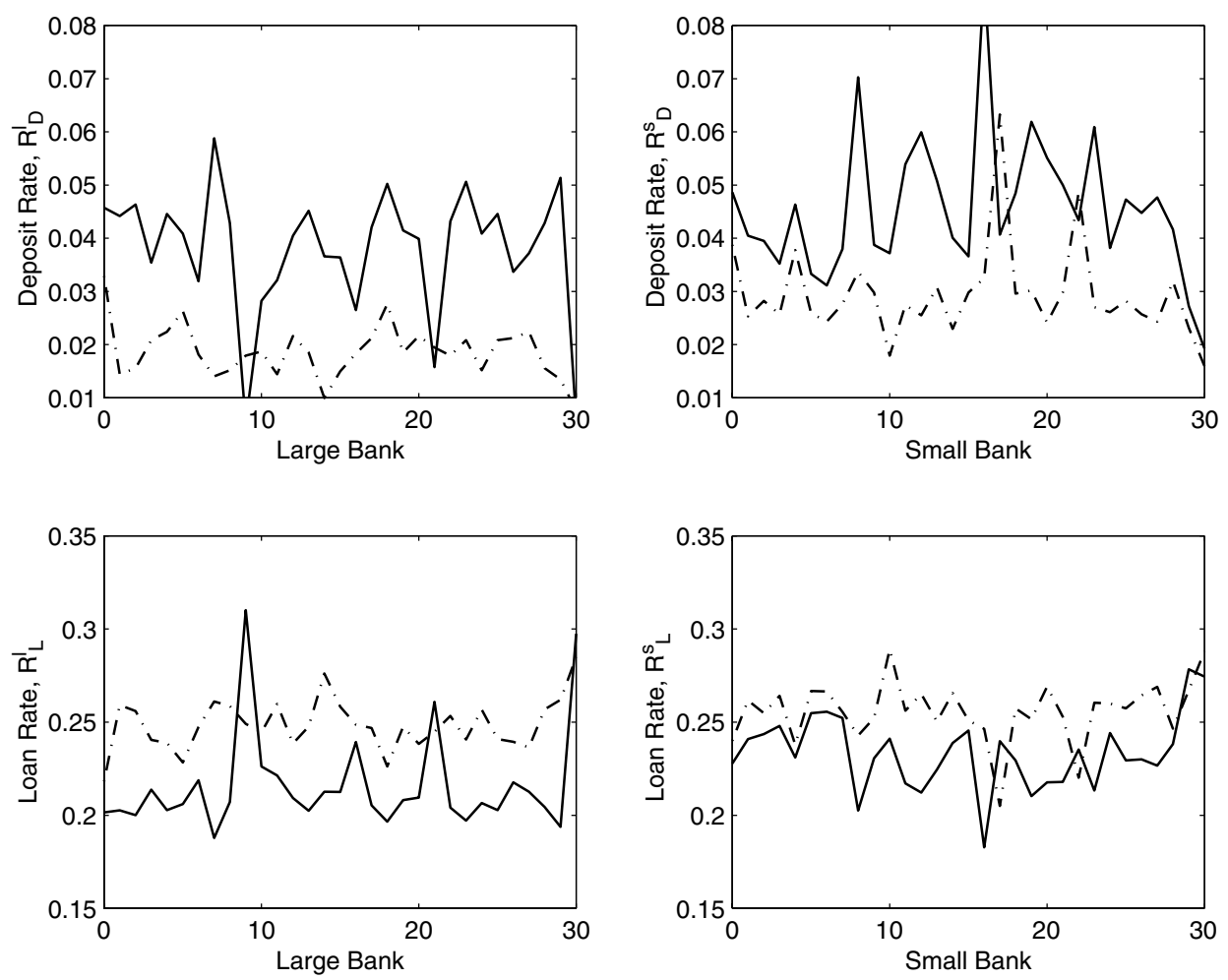

Fig. 2. Loan and deposit rates over time in the case of flat rate versus adjusted-rate premiums (dotted lines) where $\psi_{2}=0.03$.

results in the contraction of the loanable funds. Moreover, declining available funds in the banking sector are sold at higher prices, thus the optimal spreads expand for both types of banks. Nevertheless, the general result of the model that suggests higher spreads for both types of banks is more desirable in terms of insulating banks from potential shocks.

We posit that the deposit insurance premium for each bank is further adjusted whenever a bank chooses net interest margins on deposits and loans beyond the operating band for intermediation spread. Obviously, the width of this band may have an impact on the behavior of competing intermediaries. In order to explore this relationship, the same deposit game, imposing narrower $[0.1,0.20]$ and wider $[0.1,0.30]$ bands for the bank spreads, is numerically demonstrated (Figure 3). It is apparent that whatever the width, it would not be optimal for each bank to increase its deposit rates since premiums are calculated on the amount of deposits. As may also be seen from Table 1, on average, both types of banks collect less money 

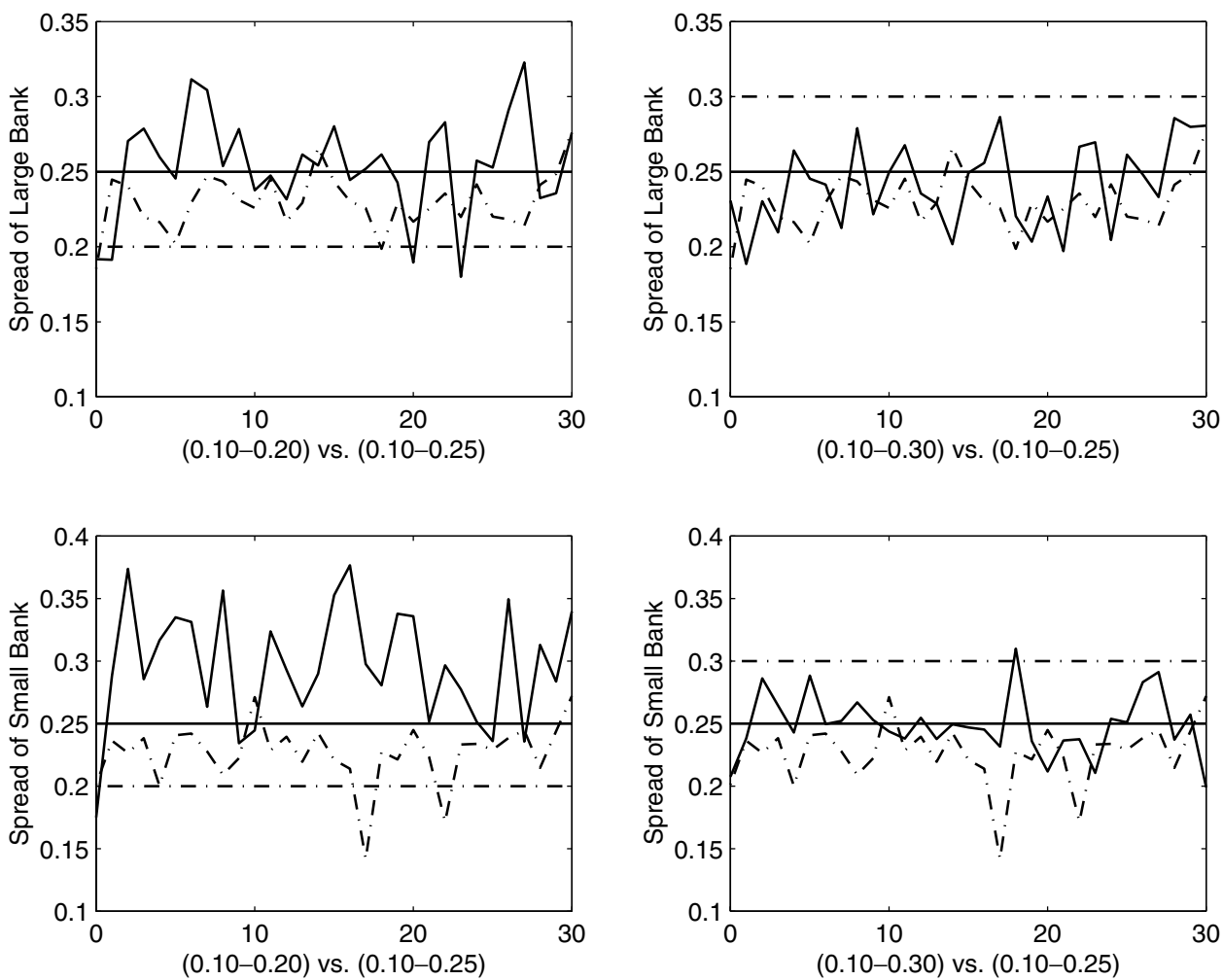

Fig. 3. Spread profiles for benchmark case with different pre-specified bands. Dotted lines represent the benchmark band of $0.10 \leq \mu \leq 0.25$.

with lower deposit rates and sell these loanable funds at higher prices in the credit market. More specifically, when the band is narrow, none of the banks is able to offer a spread within the band. Thus, the introduction of an unattainable upper limit causes more volatile and larger spreads for both banks. In the model, bank managers who try to avoid additional insurance premium payments reduce deposit collection attempts by offering lower deposit rates. Consequently, both loan rates and intermediation spreads of all banks will increase. In the experiment where there is a wider operating band, we obtain results similar to the benchmark case. However, the level and volatility of banks' spreads increase when the band widens (see also Table 1). Still, the close surveillance practice of using an operational band with an upper limit of $0.30(=\bar{\mu})$ produces less volatile spread profiles than no band.

We also numerically analyze the effect of banks' credit-risk management efforts on spreads. In particular, we concentrate on the credit-rationing 

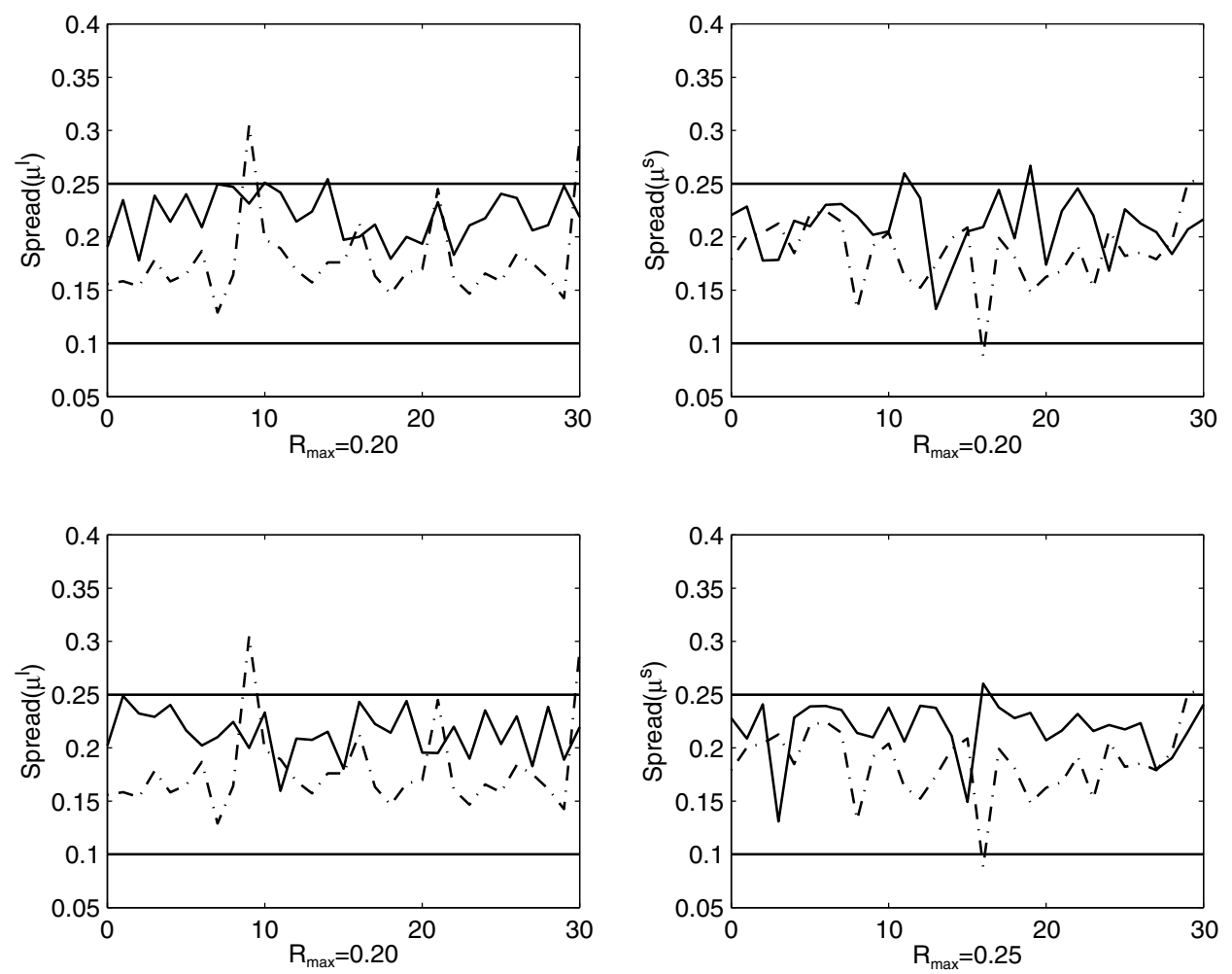

Fig. 4. Spread profiles for flat rate deposit insurance system are represented by dotted lines.

parameters of the model, $R_{\max }$ and $h$. For higher values of bank-optimal loan rates such as $R_{\max }=0.20$ and 0.25 , similar results are observed: that adjusted premium schema based on bank interest margins and credit risk bring more stable, but larger, spreads to the banking sector (Figure 4). If a bank increases its optimal loan rate, the credit-risk management strategy of credit rationing might be relaxed to a certain extent. Since a bank's expectation of default risk below this new rate is decreased, the bank will attempt to sell more loans. Hence, the attempts to collect more loanable funds will increase deposit rates, especially for competing banks. However, banks will decrease loan rates in order to sell these collected funds. Thus, the spread between deposit and loan rates would decline based on the change in the bank's judgment of its optimal loan rate. In the experiment that $R_{\max }$ is $20 \%$, on average, the spread for a large (small) bank is $0.2195(0.2104)$ with a standard deviation of 0.02251 (0.02866). Increasing $R_{\max }$ to $25 \%$ lowers the mean values of spread for both types of banks. For the large (small) bank, 

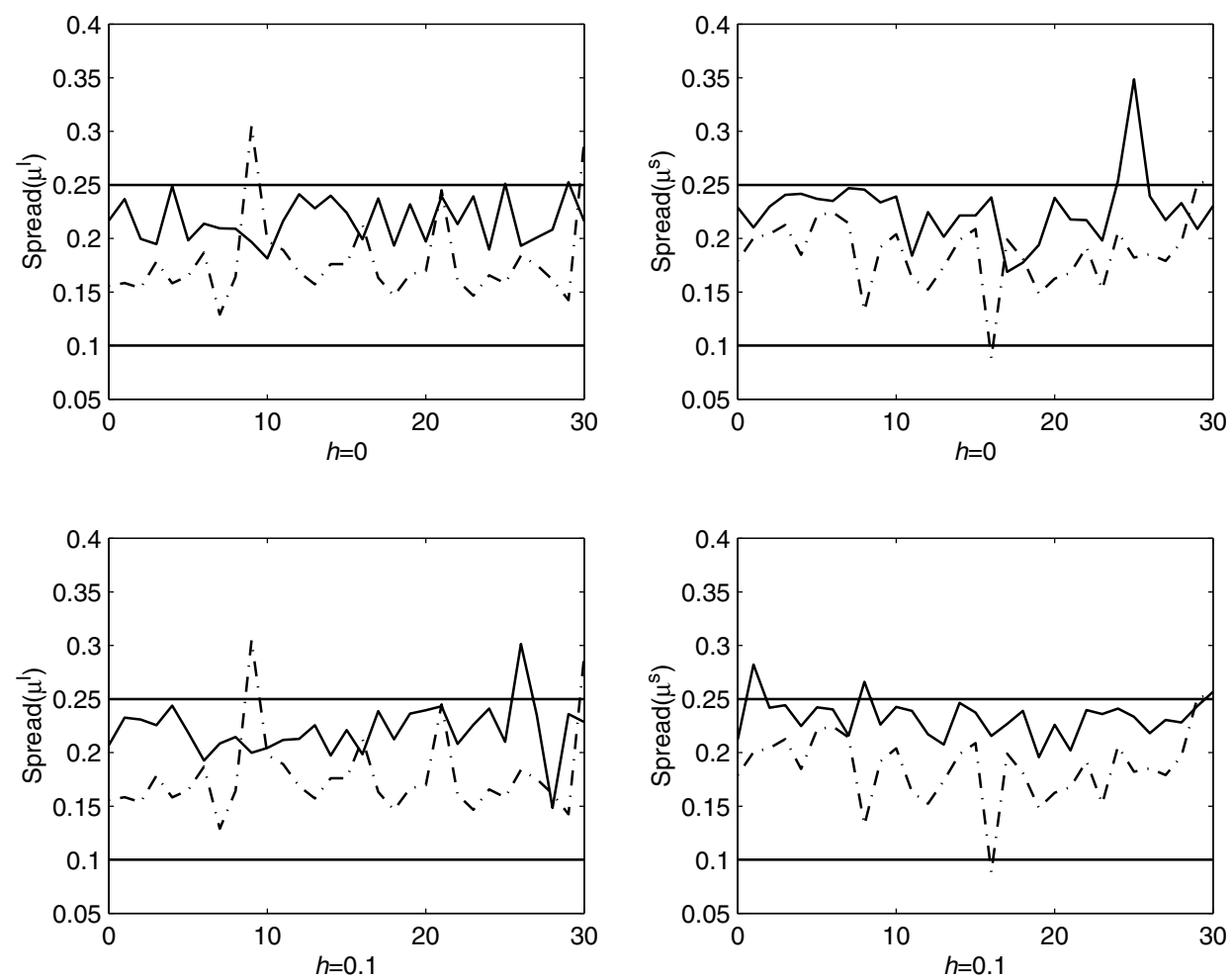

Fig. 5. Spread profiles for flat rate deposit insurance system are represented by dotted lines.

the mean spread is $0.2139(0.2185)$ and the standard deviation is 0.02145 (0.02674).

Finally, lowering or ignoring the adjustment parameter of credit rationing, $h$ yields similar spread profiles when the flat- and adjustedpremium schemata are compared (Figure 5). The mean values of spreads and the volatility over time increase with respect to the result in the benchmark case. Specifically, in the experiment where $h=0.1$, it is found that for the large (small) bank, the mean spread is 0.2139 (0.2185) and the standard deviation is $0.02145(0.02674)$. For $h=0$, the mean value of spread for the large (small) bank is $0.2195(0.2104)$ and the standard deviation is 0.02251 (0.02866). A similar explanation is valid for the change in spread behaviors of both banks. Again, bank management's decreasing expectation of default increases the amount of loans supplied at each period. As this behavior may result in collecting more loanable funds and selling them at lower prices, the difference between loan and deposit rates shrinks. 


\section{Conclusion}

In this paper, a stylized model is introduced to further understand the optimal determination of intermediation spread profiles in the competitive environment of banking. In the literature, it has been recognized that spreads between lending and deposit rates vary within and across countries according to the degree of bank competition in each country. In order to consider the banking structure in a specific economy, a multi-period noncooperative Bertrand deposit game played between small and large banks is constructed. Banks collecting deposits from investors price these funds to meet uncertain loan demands. The outcome of this game determines the optimal spreads for different types of banks over a finite time horizon. The main argument in this study is that higher or lower bank interest margins indicate credit and/or interest rate risks that should be supervised closely to obtain a more stable banking sector. It is shown that competition between small and large banks and imposing lower and upper limits on spreads lead to predictable spreads but less intermediation benefits, over time.

Although increasing bank spreads can be considered as an indication of inefficient financial intermediation, there are some desirable features. Barajas et al. (1999) point out that while a high level of spread is generally indicative of inefficiency, excessive risk taking, or lack of competition within the banking sector, it is also true that high spread can contribute to high bank earnings, which, if channeled into the system's capital base, may promote safety and stability.

Due to tractability, we have relied on various assumptions and parameters. Hence, it would be interesting to relax some of these assumptions for future research. For example, one can introduce a third player, a supervisor to the model. The supervisor may optimally choose a regulating rule according to the preferences described, namely the weights given to volatility and level of spread to maximize social welfare. In a three-period model, Chiang et al. (2007) show that optimum risk-based premium rate that is determined by the insurance agency reduces banks' choices of taking risk and raises the expected social welfare. However, Chu (2003) finds that social welfare gains disappear in the long run because deposit insurance schemes result in misallocation of resources due to increased banking regulations. Moreover, he shows that the derivation of the welfare implication of a deposit insurance scheme suffers from complexity in institutional and regulatory environment in addition to time dimensions. Hence, the welfare implications of increased 
regulation and reduced volatility of intermediation costs need a different dynamic setting.

\section{Acknowledgments}

I would like to thank Seleuk Caner, Tarık Kara, and Steven Ongena for their helpful comments and suggestions.

\section{References}

Allen, F and D Gale (2004). Competition and financial stability. Journal of Money Credit and Banking, 36, 453-480.

Allen, L (1988). The determinants of bank interest margins: A note. Journal of Financial and Quantitative Analysis, 23, 231-235.

Allen, F, H Gersbach, JP Krahnen and AM Santomero (2001). Competition among banks: Introduction and conference overview. European Finance Review, 5, $1-11$.

Angbazo, L (1997). Commercial bank net interest margins, interest-rate risk and off-balance sheet banking. Journal of Banking and Finance, 21, 55-87.

Avery, RB and TM Belton (1987). A comparison of risk-based capital and riskbased deposit insurance. Federal Reserve Bank of Cleveland, Economic Review, Quarter 4, 20-30.

Barajas, A, R Steiner and N Salazar (1999). Interest spreads in banking in Colombia 1974-1996. IMF Staff Papers, 46, 196-224.

Barnhill, TM, P Papapanagiotou and MR Souto (2004). Preemptive strategies for the assessment and management of financial system risk levels. Review of Pacific Basin Financial Market and Policies, 7, 1-42.

Barro, RJ (1976). The loan market collateral rates of interest. Journal of Money Credit Banking, 8, 439-456.

Barth, JR, M Bertus, J Hai and T Phumiwasana (2008). A cross-country assessment of bank risk-shifting behavior. Review of Pacific Basin Financial Market and Policies, 11, 1-24.

Bassett, WF and TF Brady (2001). The economic performance of small banks 1985-2000. Federal Reserve Bulletin, November, 719-728.

Berthelemy, JC and A Varoudakis (1996). Models of financial development and growth. In Financial Development and Economic Growth, N Hermes and R Lensink (eds.), 7-36. London and New York: Routledge.

Boot, A and AV Thakor (1994). Moral hazard secured lending in an infinitely repeated credit market game. International Economic Review, 35, 899-920.

Boot, A, TT Milbourn and S Dezelan (2001). Regulation and the evolution of the financial services industry. In Challenges for Central Banking, AM Santomero, S Viotti and A Vredinin (eds.), 39-58, Norwell. Massachusetts: Kluwer Academic Publishers.

Boyd, JH and G de Nicoló (2005). The theory of bank risk taking competition revisited. Journal of Finance, 60, 1329-1343. 
Britran, GR and M Lojo (1993). A framework for analyzing services operations. European Management Journal, 11, 271-282.

Chiang, TF, EC Wu and MT Yu (2007). Premium setting and bank behavior in a voluntary deposit insurance scheme. Review of Quantitative Finance and Accounting, 29, 205-222.

Chu, KH (2003). Deposit insurance and banking crises in the short and long run. Cato Journal, 23, 265-280.

Cordella, T and EL Yeyati (2002). Financial opening deposit insurance risk in a model of banking competition. European Economic Review, 46, 471-485.

Degryse, H and P Van Cayseele (2000). Relationship lending within a bank-based system: Evidence from European small business data. Journal of Financial Intermediation, 9, 90-109.

Dell'Ariccia, G, E Friedman and R Marquez (1999). Adverse selection as a barrier to entry in the banking industry. RAND Journal of Economics, 30, 515-534.

Deshmukh, SD, SI Greenbaum and G Kanatas (1983). Lending policies of financial intermediaries facing credit funding risk. Journal of Finance, 38, 873-886.

De Zeeuw, AJ and F van der Ploeg (1991). Difference games policy evaluation: A conceptual framework. Oxford Economic Papers, 43, 612-636.

Drummond, P, AM Maechler and S Marcelino (2007). Italy-assessing competition and efficiency in the banking system. IMF Working Paper, WP/07/26.

Elsas, R and JP Krahnen (1998). Is relationship lending special? Evidence from Credit-File Data in Germany. Journal of Banking Finance, 22, 1283-1316.

Flannery, MJ and KP Rangan (2002). Market forces work in the banking industry from the capital buildup of the 1990s. Mimeo. University of Florida.

Freixas, X and JC Rochet (1997). Microeconomics of Banking. Cambridge, Massachusetts: MIT Press.

Fry, MJ (1988). Money Interest Banking in Economic Development. Baltimore, MD: Johns Hopkins University Press.

Greenbaum, SI, G Kanatas and I Venezia (1989). Equilibrium loan pricing under the bank-client relationship. Journal of Banking Finance, 13, 221-235.

Gorton, G and A Winton (1998). Banking in transition economies: Does efficiency require instability? Journal of Money, Credit, and Banking, 30, 621-650.

Hannan, TH and AN Berger (1991). The rigidity of prices: Evidence from the banking industry. American Economic Review, 81, 938-945.

Hellmann, TF, KC Murdock and JE Stiglitz (2000). Liberalization moral hazard in banking prudential regulation: Are capital requirements enough? American Economic Review, 90, 147-165.

Ho, TSY and A Saunders (1981). The determinants of bank interest margins: Theory empirical evidence. Journal of Financial Quantitative Analysis, 16, 581-600.

Hoshino, Y and SJ Turnbull (2002). Further study on the performance of mergers among credit associations in Japan. Review of Pacific Basin Financial Markets and Policies, 5, 395-416.

Keeley, MC (1990). Deposit insurance, risk, and market power in banking. American Economic Review, 80, 1183-1200.

Knuth, DE (1981). Seminumerical Algorithms. Reading, MA: Addison-Wesley. 
Koch, EB (2007). Financial intermediation: Efficiency, fragility and polices for reform. In Challenges at the Bank for International Settlements, 301-320, Berlin Heidelberg: Springer-Verlag.

Laeven, L and G Majnoni (2005). Does judicial efficiency lower the cost of credit? Journal of Banking and Finance, 29, 1791-1812.

Matutes, C and X Vives (2000). Imperfect competition risk taking regulation in banking. European Economic Review, 44, 1-34.

Montgomery, J (1991). Market segmentation and 1992: Toward a theory of trade in financial services. In Financial Regulation and Monetary Arrangements After 1992, MFC Whilborg and T Willett (eds.), 173-199, New York: North-Holland.

Morgan, DP and AB Ashcraft (2003). Using loan rates to measure regulate bank risk: Findings immodest proposal. Journal of Financial Services Research, 24, $181-200$.

Pasiouras, F, C Gaganis and C Zopounidis (2006). The impact of bank regulations, supervision, market structure, and bank characteristics on individual bank ratings: A cross-country analysis. Review of Quantitative Finance and Accounting, $27,403-438$.

Petersen, MA and RG Rajan (1995). The effect of credit market competition on lending relationships. Quarterly Journal of Economics, 110, 407-443.

Pyle, DH (1974). The losses on saving deposits from interest rate regulation. Bell Journal of Economics and Management Science, 5, 614-622.

Rojas-Suarez, L (2001a). Can international capital standards strengthen banks in emerging markets? Working Paper, WP01-10, Institute for International Economics, Washington D.C.

Rojas-Suarez, L (2001b). Rating banks in emerging markets: What credit rating agencies should learn from financial indicators. Working Paper, May 2001, Institute for International Economics.

Saunders, A and L Schumacher (2000). The determinants of bank interest rate margins: An international study. Journal of International Money Finance, 19, 813-832.

Sealey, Jr CW (1980). Deposit rate-setting risk aversion the theory of depository financial intermediaries. Journal of Finance, 35, 1139-1154.

Sharpe, SA (1990). Asymmetric information bank lending implicit contracts: A stylized model of customer relationships. Journal of Finance, 45, 1069-1087.

Stein, JC (1998). An adverse-selection model of bank asset liability management with implications for the transmission of monetary policy. RAND Journal of Economics, 29, 466-486.

Stiglitz, JE and A Weiss (1981). Credit rationing in markets with imperfect information. American Economic Review, 71, 393-410.

Taggart, RA and SI Greenbaum (1978). Bank capital public regulation. Journal of Money Credit Banking, 10, 158-169.

Tirapat, S (2002). Risk-based deposit insurance: An application to Thailand. Review of Pacific Basin Financial Markets and Policies, 5, 149-179.

Tufano, P (1989). Financial innovation and first-mover advantages. Journal of Financial Economics, 25, 213-240. 
Wong, KP (1997). On the determinants of bank interest margins under credit interest rate risks. Journal of Banking Finance, 21, 251-271.

Yanelle, MO (1997). Banking competition market efficiency. Review of Economic Studies, 64, 215-239.

Zhou, X, KP Chang, X Hou and J Shengliang (2009). Endogenous timing and banking competition in a mixed oligopoly: A theoretical perspective on the banking industry in China. Working Paper, Jinhe Centre of Economic Research, Jiaotong University.

Zhu, J, MW Chen and W Li (2009). Recent changes in the prime rate behavior. Review of Quantitative Finance and Accounting, 33, 177-192. 
Copyright of Review of Pacific Basin Financial Markets \& Policies is the property of World Scientific Publishing Company and its content may not be copied or emailed to multiple sites or posted to a listserv without the copyright holder's express written permission. However, users may print, download, or email articles for individual use. 